\title{
Cyberbullying among Colombian students: an exploratory investigation
}

\author{
Giulia Mura and Davide Diamantini \\ Università degli Studi di Milano (Italy)
}

\begin{abstract}
Cyberbullying is a recognized and growing Internet phenomena. Although the body of research on this subject is rapidly expanding, most of the research has focused on the experiences of adolescents in industrialized nations, like Western Europe or Anglo-Saxon countries. But are the youth of developing countries exposed to the same risks? To address this question, this paper presents part of the results of a larger research project, and focuses on the occurrence of cyberbullying among Colombian high-school students. Data was collected on a sample of 359 respondents, $64.1 \%$ male and $35.9 \%$ female, between 13 and 19 years of age, using a pen and paper questionnaire. The analysis shows that episodes of cyberbullying are quite widespread among the sample group, as more than $60 \%$ of the sample group had been involved (as a victim or as a bully) in at least 2 episodes in the six months previous the research. Differences among sexes are analysed, but no significant result is shown. In conclusion, this study strongly suggests the necessity of deeper and wider investigation of cyberbullying among both boys and girls of the so called "developing countries", as the diffusion of the phenomena seems to affect the youth of these countries too.
\end{abstract}

Key words: Cyberbullying diffusion, youth, Colombia, sex differences.

El Ciberacoso entre los estudiantes de Colombia: una investigación exploratoria. El ciberacoso es un fenómeno relacionado con internet, reconocido y en crecimiento. Aunque el enfoque de la investigación en este campo está expandiéndose rápidamente, la mayoría de las investigaciones se centraron en las experiencias de adolescentes en países industrializados, como los de Europa occidental o países anglosajones. Pero, los jóvenes de los países en desarrollo ¿están expuestos a los mismos riesgos? Para responder a esta pregunta, este trabajo presenta una parte de los resultados de un proyecto más amplio, y centra su atención en la incidencia de episodios de ciberacoso entre los estudiantes de secundaria en Colombia. Los datos se recogieron sobre una muestra de 359 estudiantes, $64.1 \%$ varones y $35.9 \%$ mujeres, entre los 13 y los 19 años de edad, utilizando un cuestionario entregado en horario escolar. El análisis demuestra que los episodios de ciberacoso están bastante extendidos en el grupo de la muestra; teniendo en cuenta que más del $60 \%$ de los jóvenes entrevistados estuvo involucrado (ya sea como víctima o como acosador) en al menos 2 episodios en los 6 meses anteriores a la investigación. Las diferencias entre los sexos han sido analizadas, pero no han dado resultados significativos. En conclusión este estudio pone en evidencia la necesidad de una investigación más profunda y amplia del ciberacoso, tanto entre la población masculina como entre la femenina, de los así llamados "países en desarrollo", porque parece que la difusión de éste fenómeno está afectando también a la juventud de éstos países.

Palabras clave: Difusión del ciberacoso, jóvenes, Colombia, diferencias entre sexos.

Correspondence: Giulia Mura. Università degli Studi di Milano-Bicocca. Centro Interdipartimentale Quasi. Piazza Ateneo Nuovo, 1. C.P. 20123. Milano (Italy). E-mail: giulia.mura@unimib.it 
The diffusion of ICT is a recognized phenomenon involving all worlds' countries. According to the International Telecommunications Union between 2006 and 2011 the worldwide proportion of Internet users on the global population went from the $18 \%$ to the $35 \%$. If the diffusion rates in developed countries are already very high, the last decade increase of Internet penetration in the developing countries has been striking: between 2000 and 2012 African countries have seen a growth of 3,606.7\% in Internet penetration rate, and Latin America/ Caribbean countries witnessed a 1,310.8\% increase (data from the Internet World Stat, 2013).

In May 2011 the Cisco Broadband Barometer reported a growth of $20.8 \%$ in the number of fixed broadband Internet connections in Colombia during 2010, and an increase of $59.21 \%$ in mobile connections during the same period. The more recent "Cisco Broadband Barometer 2.0 report" states that, in June 2012, Colombia reached a total of 4.72 million connections and is expected to exceed 8.5 million connections, both fixed and mobile by 2016. Moreover, according to the Internet World Stat website, in 2012 Facebook users were 16,825,840, which means a penetration rate of $37.2 \%$.

When investigating the diffusion of ICT all over the world, surveys generally highlight the relevance of the youngest as informational technology users. According to Mora-Merchán and Jäger, in 2010 approximately 52\% of the European population was online but for young people (between 6 and 17 years), Internet use had an average rate of $75 \%$. In many countries like Finland, Norway, Denmark, the Netherlands, Sweden, Germany and the UK, 95\% (or more) of young people were already online. New technologies appear to have become an integral part of the lives of young people, although their use is changing constantly. For instance, whereas in the 90s Internet was used primarily for entertainment (Valkenburg and Soeters, 2001), at the present the predominant use is for interpersonal communication (Gross, 2004; Lenhart, Madden and Hitlin, 2005). A recent survey conducted by the EU KIDS Online (2011) project estimated that $62 \%$ of 9 to 16 year old Europeans used SNSs, either owning a profile or visiting the one of a friend. One quarter $(26 \%)$ of the 9-10 year olds interviewed reported having their own profile, compared with half (49\%) of 11-12 year olds. For teenagers, percentages were much higher: $73 \%$ of the $13-14$ year olds and $82 \%$ of the $15-16$ year olds.

\section{Cyberbullying, a new international concern}

This wide diffusion of communication opportunities leads to a number of advantages, but also concerns arise among parents and educators, still unsure about the potential risks that digital natives may face, and that can be difficult to foresee by those belonging to the digital immigrant generation. For instance, in a survey released in 2009 and promoted by Common Sense Media, a sample of 1000 teens were interviewed about their behaviours on SNS. Researchers found that at least a quarter of the young people 
polled had posted something they later regretted, made fun of others or created a false identity online, and one out of ten had posted a nude or semi-nude picture of themselves (Tucker, 2009). When we talk about cyberbullying, we refer to all the forms of bullying and aggression carried out through the use of new technologies, especially mobile phones and the Internet. Cyberbullying is one of the major issues arising from the diffusion of ICT among teens and pre-teens.

In one of the most quoted analysis of the forms that the phenomenon can take, Willard (2007) identifies seven categories of common cyberbullying actions: flaming (sending angry, rude, vulgar messages about a person); online harassment (repeatedly sending offensive, rude and insulting messages via email or other text messaging to a person); denigration (sending harmful, untrue, or cruel statements or gossip about a person to other people or posting such material online); impersonation (pretending to be someone else by breaking into his/her account or creating a fake one, and sending or posting material that makes that person look bad, get that person in trouble or danger, or damage that person's reputation or friendships); outing and trickery (sending or posting material about a person that contains sensitive, private, or embarrassing information, including forwarding private messages or images, but also tricking someone into revealing secrets or embarrassing information, which is then shared online); exclusion (intentionally excluding someone from an online group); cyberstalking (repeatedly sending messages that include threats of harm or are highly intimidating or engaging in other online activities that make a person afraid about personal safety). However, given the newness of the phenomenon, a clear definition of cyberbullying is not yet available (Grigg, 2010) and substantial differences can be found in the definitions adopted by the surveys trying to build a first body of knowledge on this problem. The lack of uniformity in the criteria adopted, such as the one regarding the time window taken into account, or the repetition of the episodes as a necessary condition in order to consider a cyber-attack as bullying, create difficulties in the comparison of the studies realized so far. Still, research findings from around the world suggest that cyberbullying is an internationally diffused problem. For example, researchers from England (Smith, Mandavi, Carvalho, and Tippett, 2005), Canada (Li, 2006), Belgium (Vandebosch, Van Cleemput, Mortelmans and Walrave, 2006), Sweden (Slonje and Smith, 2008), Turkey (Erdur-Baker, 2010), Italy (Saputo and Pisano, 2008), the USA (Kowalski and Limber, 2007), India (Halder and Jaishankar 2007) and China (Hong, Li, Mao and Stanton 2007) reported that episodes of cyberbullying have been experienced by the youth interviewed. Such results clearly suggest that cyberbullying is a rapidly emerging problem across different age groups regardless of their cultural background. However, most of the relevant research has focused on the experiences of adolescents in industrialized nations, Western European or North American in most of the cases, while much less is known about the digital safety and risks of adolescents in developing countries. As pointed out 
by Grasser, Maclay and Palfrey (2010) this knowledge gap is particularly relevant once we observe that the differences in access to Internet and communication technologies between industrialized and developing nations are narrowing.

As introduced, Colombia is experiencing a rapid increase in ICT diffusion, and little research is available to describe the impact that such change is having on preteens and teens. In a study published in 2010, Arango Forero, Bringué Sala and Sádaba Chalezquer observed that although the possibility to access Internet from home was not widely diffused among the Colombian youth, this didn't lead to a lack of Internet usage. Among the interviewed sample (3292 students between 10 and 18 years, living in urban areas and attending school), $45.9 \%$ declared to use the Internet mainly from college, $39.8 \%$ from Internet cafes, and only $30.3 \%$ from home. Moreover, the $56.8 \%$ of the respondents used Messenger, and $53.3 \%$ email.

With the present study, we try to have a look at the occurrence of cyberbullying among Colombian students, collecting a sample of data that could be useful in orienting further and wider research.

\section{METHOD}

\section{Participants}

The sample is composed of 360 students of secondary school, 64\% male and $36 \%$ female, distributed between public $(59 \%)$ and private $(41 \%)$ institutes. The age range between 14 and 19 years $(M=16 ; S D=1.11)$. The parental level of education among the respondents is quite high, with more than $50 \%$ of both fathers and mothers having attended university. Moreover, most of the fathers (86\%) and mothers (65\%) work as managers/entrepreneurs, employees or freelance, while the rate of unemployed is very low.

\section{Instruments and Procedure}

A pen and paper questionnaire was created for this aim, and submitted to a sample of students during school hours. Firstly, the questionnaire asked to rate the frequency of mobile phone and Internet use on a Likert scale going from "never" to "more than once a day".

Cyberbullying experiences were measured by a total of 16 items ( 8 for cyber bullying and 8 for cyber victimization). The items were constructed upon reviewing several international studies and were based on the Revised Cyber Bullying Inventory (RCBI; Topcu and Erdur-Baker, 2010). Students were asked to respond to each item on a three point rating scale ( $1=$ never to $3=3$ times or more) indicating the frequency of their engaging/facing particular cyberbullying acts in the previous 6 months.

While analyzing the data, four categories were created: not involved, involved only as victims (at least two episodes reported) involved only as a bully (at least two 
episodes reported) involved as bully-victims (at least two episodes as a victim and two episodes as bully reported). Demographic information on the respondents (age, gender, parental education level, parental occupation and type of school attended) were also required.

\section{RESULTS}

The respondents are a group of highly connected teens: $75 \%$ use the mobile phone at least once a day, and $80 \%$ use Internet with the same frequency. No significant difference is found in the use of mobile phones between public and private school students (they use it at least once a day in $76 \%$ and $73 \%$ respectively, of the cases). $74 \%$ of the public school respondents and $88 \%$ of the private school respondents use the Internet at least once a day. The difference in Internet use between the two groups is statistically significant, but the strength of the connection is very weak: $\chi_{(4, N=357)}^{2}=12.92$, $p<.05$; Cramer's V $=.190, p<.05$. When asked to evaluate the frequency of involvement in acts of cyberbullying, $69 \%$ of the sample declared to have been victim of at least two episodes of cyberbullying in the previous six month, and $62 \%$ stated to have carried out at least two acts of cyberbullying.

Looking at item by item frequency of cyberbullying victimization, $45 \%$ reported having received prank calls, $40 \%$ a mean comment on a social network site, $37 \%$ was victim of online gossip, $31 \%$ received a mean or threatening email, $30 \%$ had a private message published without permission, $26 \%$ had an embarrassing photo published without permission, $24 \%$ have been excluded from a forum online and $19 \%$ had their online ID stolen.

Table 1. Cyberbullying experiences for male and female respondents

\begin{tabular}{|c|c|c|c|c|c|c|c|c|c|c|c|}
\hline & & & & Victim & & & & & Bull & & \\
\hline & & $\begin{array}{c}\text { Never } \\
(\%)\end{array}$ & $\begin{array}{c}\text { Once } \\
\text { or } \\
\text { twice } \\
(\%)\end{array}$ & $\begin{array}{c}\text { Three } \\
\text { times } \\
\text { or more } \\
(\%)\end{array}$ & $\chi^{2}(p)$ & $V(p)$ & $\begin{array}{c}\text { Never } \\
(\%)\end{array}$ & $\begin{array}{c}\text { Once } \\
\text { or } \\
\text { twice } \\
(\%)\end{array}$ & $\begin{array}{c}\text { Three } \\
\text { times or } \\
\text { more } \\
(\%)\end{array}$ & $\chi^{2}(p)$ & $V(p)$ \\
\hline \multirow{2}{*}{$\begin{array}{l}\text { Email/ } \\
\text { SMS }\end{array}$} & $\mathrm{M}$ & 70.7 & 21.4 & 7.9 & $5.86(.053)$ & $128(.053)$ & 81.3 & 15.7 & 3.0 & & \\
\hline & $\mathrm{F}$ & 66.7 & 30.2 & 3.1 & & & 85.3 & 12.4 & 2.3 & & \\
\hline SNS & $\mathrm{M}$ & 63.9 & 27.8 & 8.3 & & & 62.6 & 30.0 & 7.4 & & \\
\hline Forum & $\mathrm{F}$ & 76.7 & 20.9 & 2.3 & & & 68.2 & 22.5 & 9.3 & & \\
\hline \multirow{2}{*}{ Gossip } & $\mathrm{M}$ & 65.2 & 22.6 & 12.2 & & & 70.0 & 23.5 & 6.5 & & \\
\hline & $\mathrm{F}$ & 59.7 & 27.1 & 13.2 & & & 79.8 & 17.8 & 2.3 & & \\
\hline \multirow{2}{*}{$\begin{array}{l}\text { Photo/ } \\
\text { video }\end{array}$} & $\mathrm{M}$ & 72.2 & 19.6 & 8.3 & & & 80.9 & 12.2 & 7.0 & & \\
\hline & $\mathrm{F}$ & 77.5 & 18.6 & 3.9 & & & 84.5 & 14.0 & 1.6 & & \\
\hline \multirow{2}{*}{ ID theft } & $\mathrm{M}$ & 84.3 & 14.3 & 1.3 & $7.82(.02)$ & $.148(.02)$ & 87.8 & 9.6 & 2.6 & & \\
\hline & $\mathrm{F}$ & 76.0 & 17.8 & 6.2 & & & 86.8 & 7.8 & 5.4 & & \\
\hline
\end{tabular}


Concerning item by item frequency of the cyberbullying carried out by the respondents, $48 \%$ report having made prank calls, 37\% left a mean comment on someone's social network page, $35 \%$ excluded someone from an online forum, $26 \%$ spread an online gossip, $26 \%$ published someone's private message without permission, $18 \%$ published someone's photo without permission, $17 \%$ sent at least one threatening email, $13 \%$ stole someone's online ID.

Table 2. Cyberbullying experiences among public and private school students

\begin{tabular}{|c|c|c|c|c|c|c|c|c|c|c|c|}
\hline & \multicolumn{6}{|c|}{ Victim } & \multicolumn{5}{|c|}{ Bully } \\
\hline & & $\begin{array}{c}\text { Never } \\
(\%)\end{array}$ & $\begin{array}{c}\text { Once } \\
\text { or } \\
\text { twice } \\
(\%)\end{array}$ & $\begin{array}{c}\text { Three } \\
\text { times or } \\
\text { more } \\
(\%)\end{array}$ & $\begin{array}{l}\chi^{2} \\
(p)\end{array}$ & $\begin{array}{c}V \\
(p)\end{array}$ & $\begin{array}{c}\text { Never } \\
(\%)\end{array}$ & $\begin{array}{c}\text { Once or } \\
\text { twice } \\
(\%)\end{array}$ & $\begin{array}{c}\text { Three } \\
\text { times or } \\
\text { more } \\
(\%)\end{array}$ & $\chi^{2}(p)$ & $V(p)$ \\
\hline \multirow{2}{*}{$\begin{array}{l}\text { Email/S } \\
\text { MS }\end{array}$} & Pub & 71.2 & 22.2 & 6.6 & & & 84.0 & 13.6 & 2.3 & & \\
\hline & Priv & 66.0 & 28.6 & 5.4 & & & 81.0 & 15.6 & 3.4 & & \\
\hline \multirow{2}{*}{ SNS } & Pub & 62.0 & 29.6 & 8.5 & & & 64.8 & 28.6 & 6.6 & & \\
\hline & Priv & 57.8 & 35.4 & 6.8 & & & 59.2 & 34.0 & 6.8 & & \\
\hline \multirow{2}{*}{ Forum } & Pub & 73.2 & 20.2 & 6.6 & & & 59.6 & 29.1 & 11.3 & $6.7(.035)$ & $.137(.035)$ \\
\hline & Priv & 79.6 & 17.7 & 2.7 & & & 72.8 & 20.4 & 6.8 & & \\
\hline \multirow{2}{*}{ Gossip } & Pub & 63.4 & 25.4 & 11.3 & & & 73.7 & 20.7 & 5.6 & & \\
\hline & Priv & 63.3 & 22.4 & 14.3 & & & 73.5 & 22.4 & 4.1 & & \\
\hline \multirow{2}{*}{$\begin{array}{l}\text { Photo/vi } \\
\text { deo }\end{array}$} & Pub & 75.1 & 18.8 & 6.1 & & & 84.0 & 12.2 & 3.8 & & \\
\hline & Priv & 72.1 & 19.7 & 8.2 & & & 79.6 & 13.6 & 6.8 & & \\
\hline \multirow{2}{*}{$\begin{array}{l}\text { Priv. } \\
\text { mess. }\end{array}$} & Pub & 69.0 & 24.9 & 6.1 & & & 75.1 & 19.2 & 5.6 & & \\
\hline & Priv & 70.7 & 21.8 & 7.5 & & & 72.1 & 20.4 & 7.5 & & \\
\hline \multirow{2}{*}{$\begin{array}{l}\text { Prank } \\
\text { call } \\
\end{array}$} & Pub & 56.3 & 31.5 & 12.2 & & & 57.7 & 25.4 & 16.9 & $8.3(.016)$ & $.152(.016)$ \\
\hline & Priv & 52.4 & 32.7 & 15 & & & 42.9 & 37.4 & 19.7 & & \\
\hline \multirow{2}{*}{ ID theft } & Pub & 83.1 & 14.6 & 2.3 & & & 89.2 & 7.5 & 3.3 & & \\
\hline & Priv & 78.9 & 17.0 & 4.1 & & & 85.0 & 10.9 & 4.1 & & \\
\hline
\end{tabular}

Crossing the answers to these two set of questions it was possible to observe that the majority of the respondents $(53 \%)$ have been involved in episodes of cyberbullying both as victims and bullies. The second larger group is the one of not involved, including $22 \%$ of the respondents, while $16 \%$ belong to the only victim and only $9 \%$ to the only bully group.

When checking for gender differences, no significant result is found in the distribution between the four groups of not involved, victim only, bully only, and bullyvictim. Only extremely small differences are detected in the specific behaviours reported by the respondents (Table 1).

Similarly, no statistically significant difference is found in the distribution between the four groups of involvement on the basis of the kind of school attended, private or public and only some minor difference exist when checking the specific behaviours (Table 2).

\section{DISCUSSION AND CONCLUSIONS}

The use of ICT is widespread among the interviewed youth. From the data collected, it seems possible to affirm that the diffusion of Internet and mobile phones 
among Colombian students goes hand in hand with the rise of cyberbullying practices. The picture drawn from the data collected is similar to the ones obtained by the surveys in other countries: cyberbullying involves both boys and girls, and doesn't seem to be related to the kind of school attended. It would be necessary, however, to confront this data with that of a sample of different family backgrounds, with a lower level of education or different jobs. This study only aims at being a first, exploratory glance, and among its limitations are the dimension of the sample and the use of a self-reporting instrument, passible of over and under estimation of the problem. However, the results support the observation that cyberbullying represents a relevant problem that should be addressed also in Latino-American countries (Garcia-Maldonado, Joffre-Velazquez, Martinez-Salazar and Llanes-Castillo, 2011). We suggest the necessity of wider investigation, which may not only assess the predominance of cyberbullying episodes, but also the relevance that such episodes have in the life of teens and pre-teens. Cultural factors may well be involved in the evaluation of the cyberbullying actions and in the strategies adopted by the youth to deal with such problems, and such knowledge would greatly help the definition of the actions of prevention and support.

\section{REFERENCES}

Arango, G., Bringue, X. and Sadaba, C. (2010). La generación interactiva en Colombia: adolescentes frente a la Internet, el celular y los videojuegos, Anagramas. Rumbos y Sentidos de la Comunicación, 9(17), 45-56.

Cisco (2011). Cisco Broadband Barometer 2010, available at http://newsroom.cisco.com/pressrelease-content?type $=$ webcontent $\&$ articleId $=6049610$.

Erdur-Baker, Ö. (2010). Cyberbullying and its correlation to traditional bullying, gender and frequent and risky usage of Internet-mediated communication tools. New Media Society, 12(1), 109-125.

Garcia-Maldonado, G, Joffre-Velázquez, V.M., Martinez-Salazar, G.J. and Llanes-Castillo, A. (2011). Ciberbullying: forma virtual de intimidación escolar. Revista Colombiana de Psiquiatría, 40(1), 115-130.

Gasser, U., Maclay, C.M. and Palfrey J.G. (2010), Working towards a deeper understanding of digital safety for children and young people in developing nations. Public Law and Legal Theory Working Paper Series, Paper n. 10-36, Harvard Law School.

Grigg, D.W. (2010). Cyber-aggression: definition and concept of cyberbullying. Australian Journal of Guidance and Counseling, 20(2), 143-156.

Gross, E.F. (2004). Adolescent Internet use: What we expect, what teens report. Journal of Applied Developmental Psychology, 25, 633-649.

Halder, D. and Jaishankar, K. (2007). Bullying and Cyber Bullying in Schools: Need to address the Legal and Policy Vacuum in India, available at http://www.articleco.com/Article/Bullying-and-Cyber-Bullying-in-Schools--Needtoaddress-the-Legal-and-Policy-Vacuum-in-India/47140.

Hong, Y., Li, X., Mao, R. and Stanton, B. (2007). Internet Use Among Chinese College Students: Implications for Sex Education and HIV Prevention. Cyberpsychology and Behavior, 10(2), 161-170. 
International Telecommunications Unions (2011). The World in 2011: ITC Facts and Figures, Geneva, available at http://www.itu.int/ITUD/ict/facts/2011/material/ICTFactsFigures2011.pdf.

Kowalski, R. and Limber, S.P. (2007). Electronic bullying among middle school students. Journal of adolescent health, 41, 22-30.

Lenhart, A., Madden, M. and Hitlin, P. (2005). Teens and technology: Youth are leading the transition to a fully wired and mobile nation. Pew Internet and American Life Project, Washington, DC.

Li, Q. (2006). Cyberbullying in schools: A research of gender differences. School Psychology International, 27, 157-170.

Livingston, S., Haddon, L., Gorzig, A. and Olafsson, K. (2011), Risks and safety on the internet. The perspective of European children, Full Findings. EU Kids Online, LSE, London.

Mora-Merchán, J.A., Del Rey, R. and Jäger, T. (2010). Cyberbullying: Review of an emergent issue. In J.A. Mora-Merchán and T. Jäger: Cyberbullying: a cross-national comparison, Verlag Empirisische Pädagogik, Landau.

Topcu, Ç. and Erdur-Baker, Ö. (2010). The revised cyber bullying inventory (RCBI): Validity and reliability studies. Procedia-Social and Behavior Sciences, 5, 660-664.

Saputo, E. and Pisano L. (a cura di) (2008). Cyberbullismo, indagine esplorativa sul fenomeno delle prepotenze online, available at www.cyberbullismo.com.

Slonje, R. and Smith, P.K. (2008). Cyberbullying: Another main type of bullying? Scandinavian Journal of Psychology, 49, 147-154.

Smith, P., Mandavi, J., Carvalho, M. and Tippett, N. (2005). An investigation into cyberbullying, its forms, awareness and impact, and the relationship between age and gender in cyberbullying. University of London, Goldsmiths College, Unit for School and Family Studies.

Tucker, J. (2009). Social network has hidden dangers for teens, San Francisco Chronicle, available at http://www.sfgate.com/news/article/Social-networking-has-hidden-dangersfor-teens-3289805.php.

Valkenburg, P.M. and Soeters, K. (2001). Children's positive and negative experiences with the Internet. Communication Research, 28, 653-676.

Vandebosch, H., Van Cleemput, K., Mortelmans, D. and Walrave, M. (2006). Cyberbullying among youngsters in Flanders, available at http://www.viwta.be/files/cyberbullying\%20executive\%20overwiev.pdf.

Willard, N.E. (2007). Cyber-safe kids, cyber-savvy teens: Helping young people learn to use the Internet safely and responsibly, Jossey-Bass.

www.internetworldstats.com (2013). Internet Usage Statistics, The Internet Big Picture, World Internet Users and Population Stats, available at http://www.internetworldstats.com/stats.htm.

www.telecompaper.com (2013). Colombia ends June 2012 with 4.7 mln internet connections, available at

http://www.telecompaper.com/news/colombia-ends-june-2012-with-47-mln-internet-connections-923845?utm_source=feedburner\&utm_medium=feed\&utm_campaign=Feed $\% 3 \mathrm{~A}+\mathrm{Telec}$ ompaperInternet+\%28Telecompaper+Internet\%29

Received: February 17th, 2013

Modifications Received: March 8th, 2013

Accepted: September 16th, 2013 